\title{
Technology and Unemployment for Executives in Hospitals
}

Jayr Figueiredo de Oliveira

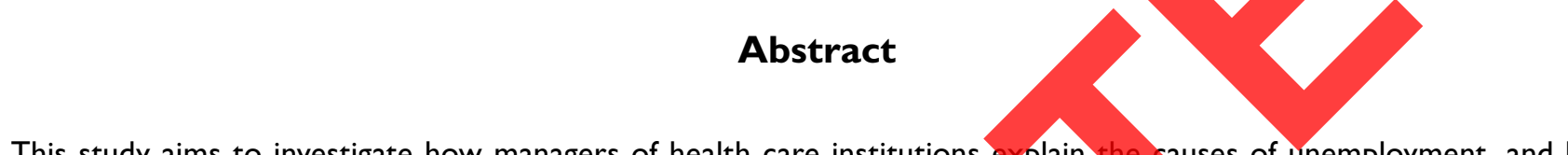

This study aims to investigate how managers of health care institutions explain the causes of unemployment, and how this explanation is related to their personal and family values, in accordance with Schwartz's theoretical model. For that, we used two questionnaires: one analyzes the explanations for unemployment, and the other one is the Portrait Values Questionnaire (PVQ 2I - short version). Employed and formerly unemployed workers do not show any significant differences in explaining the causes of unemployment. On the other hand, regarding values, formerly unemployed workers show universalism and benevolence, values related to the self-transcendence dimension. Employed workers, in turn, show values of security, related to the conservatism dimension. The conclusion is that, even though technological innovations can affect the quality and quantity of employment, it does not determine its results, especially when we consider the national economy.

Keywords: information technology; unemployment; hospital managers; formation; service management

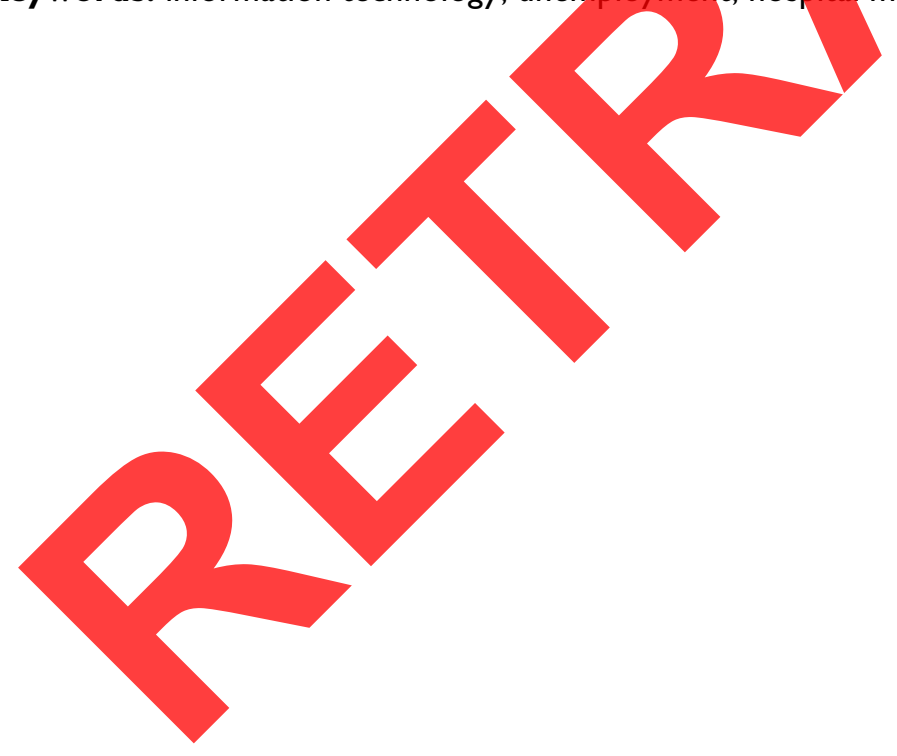

ESAESP-FGV Bachelor and Master in Business Administration, PhD in Education and Post-Doctorate in Information Technology Management. Fundação Getúlio Vargas de São Paulo - CMDA, Mediator Prof. Dr.Alberto Luiz Albertin. Alameda das Rosas, 63 - CEP 065I9-405, Santana de Parnaíba, São Paulo, Brasil.Tel: 05 I+1 I+ 99678093. jfigueiredo@usp.br 


\section{INTRODUCTION}

Since the First Industrial Revolution, people have been debating the relation between technological innovations and unemployment. These debates fluctuated according to the economic cycle. In that sense, during periods of significant growth, the dominant theses pointed out the advantages of technical progress. On the other hand, in periods of crises and when there was intense introduction of new equipment, machines, and modes of production, most analyses considered technical progress to be the only responsible for employment decrease.

According to Dowbor (2002), these arguments were aggravated by the job crisis that affected so many countries in the 1970s. At that time, the Brazilian government believed in protecting national companies, supported by IMF (International Monetary Fund) loans to promote social stability. This gave the population a false sense of social welfare, keeping them unaware of international events.

Nonetheless, in Souza's viewpoint (2008), during the following decades, there were abrupt reductions in Brazil's credit with the IMF, ending the paternalism between the government and the companies. Now, companies had to compete in the globalized world - and they started in a positio disadvantage.

As privatizations took place, the previously governmen owned companies started to worry about profit and cost reduction, giving priority to intellectual capital instead of physical work. At that point, all the workers that used to feel stability in their jobs - and believed they had their income assured until retirement - had to adapt to their new reality. At the same time that labor yelations changed, technology was playing a big role in the society, marked by its continuous changes.

In the 1970s, technology focused on electronic data processing. People believed that its use was limited to the recovery and speedy processing of data. Nowadays, there is a clear division among software, systems, and information engineerings, each one dedicated to a different technological specialty in order to offer information - data related to knowledge that provides people with useful tools in decision making (Oliveira and Mañas, 2004).

According to the annual report on worldwide employment published in 2012 by the International Labor Organization (ILO), the world faces an "urgent challenge" to create 600 million productive jobs over the next decade in order to promote sustainable growth and maintain social cohesion. "After three years of continuous crisis conditions in global labor markets and against the prospect of a further deterio- ration of economic activity, there is a backlog of global unemployment of 200 million", as stated by ILO in the annual report called "Global Employment Trends 2012: Preventing a deeper jobs crisis". Moreover, according to the same report, more than $\mathbf{4 0 0}$ million new jobs will be needed over the next decade to absorb the annual growth of labor force, estimated in $\mathbf{4 0}$ million per year.

The report adds that an additional challenge is to create decent jobs for the $\mathbf{9 0 0}$ million workers who live with their families below the poverty line of 2 dollars a day, most of them in developing countries.

"Despite strenuous government efforts, the jobs crisis continues unabated, with one in three workers worldwide - or an estimated I.I billion people - either unemployed or living in poverty", said the ILO Director-General Juan Somavia. "What is needed is that job creation in the real economy must become our number one priority".

Furthermore, the report states that the recovery that started in 2009 was short-lived, and there are still $\mathbf{2 7}$ million more unemployed workers now than there were at the beginning of the crisis. The fact that the economy is not creating enough jobs can be seen in the employment-to-population ratio (i.e., the percentage of people in working age who are employed). This ratio dropped from $61.2 \%$ in 2007 to $60.2 \%$ in 2010 , the largest drop on records.

At the same time, there are almost 29 million fewer people in the labor force now than expected based on pre-crisis trends. If these potential workers were to be counted as unemployed, the worldwide unemployment would go from 197 million to 225 million people, and the unemployment rate would increase from $6 \%$ to $6.9 \%$.

The report mentions 3 possible paths for the employment situation in the future. The baseline projection is that there will be another 3 million unemployed workers in 2012, reaching 206 million in 2016. However, if global growth rates fall below $2 \%$, unemployment would reach 204 million in 20I2. In a more optimistic scenario - assuming that the Euro debt crisis will be solved soon - worldwide unemployment would be reduced by I million in 20I2, compared to the baseline scenario.

Based on this information, we question how executives in management positions face the insecurities and challenges of these unemployment prospects and the enormous development and innovation of technology resources. 


\section{THEORETICAL FRAMEWORK}

Since the last decade of the 20th Century, the accelerated development of the technological change has been linked to the spread of the ICTs in the productive and service sector in an important group of countries, especially in those which are highly developed. Both in the United States and the European Union, the informatics and communications sector functioned as one of the main motors of the economic growth, especially during the 1990s and early 2000s (Fernández and Borjas, 2008).

One of the main consequences of the economic globalization is the continuous changes in work relations due to technological innovations that lead to many forms of productive restructuring.

Technological and organizational changes generate new professions at the same time that they suppress others. Around the world, people face the fragmentation of the job market and the increase of unemployment. These phenomena are related to the appearance of new employment contracts, other than the traditional contract for indefinite term (Faria, 2010).

One of the most recurrent discussions within the discip that study employment in companies is about the rela between employment and technological development. Th discussions are especially controversial when they refer to whether or not the economy is capable of keeping creatin jobs as sophisticated equipment are introduced.

This type of discussion is not unexpected. On the contrary, it reflects a moment of deep transformations in the technological basis, with electromechanical technology being replaced by nanotechnology. This technological leap is so enormous that many researches, like Toffler (2007), Castells (2007), Negroponte (1995), and Naisbitt (1995), even mentioned a Third Industrial Revolution. Such a leap, however, could not happen without major implications in employment. If, on one hand, we cannot deny such implications, on the other hand we must also acknowledge that technological innovations are not the only factor affecting the job market. There are many other factors that are critical to understand the current worldwide job crisis.

For Keynes, "evidence indicates that full, or even approximately full employment is of rare and short-lived occurrence" (Keynes, 1936, p. 173). This statement shows how differently Keynes perceived reality in comparison with neoclassical authors, which created the basis for disagreements in their theoretical viewpoints. In Keynes' "general theory", one way to perceive the term "general" is as the theory could explain not only full employment, but also involuntary unemployment. The neoclassical theory, in turn, could only explain the full employment situation, being, therefore, partial (Chick, 1989, p. 35-36).

However, problems related to unemployment were neither exclusive to Keynes' time, nor to developed countries. Brazil has been facing the same problems for over three decades. Even though there has not been such a disastrous situation as the one that affected the world in 1930, the problem has not ceased to appear - in larger or shorter scales - in many countries, worrying economists, governments, entrepreneurs, managers, and the society as a whole (Oliveira e Cunha, 2010).

Corporations, the foundation of capital productivity, are structured to conduct accumulation processes, fomenting changes that increase produ

Within corporations, structures and personal relationships have been increasingly rationalized, affecting the ways of living and working, and developing structures that are narrower and more flexible in terms of contract forms, as opposed to the agricultural and industrial structures from the early stages of industrialization.

Many transformations take place in the production proaffecting management strategies and relationships corporations. These changes, according to Guimarães (2002), affect both the people who survive the process, and the ones who seem to be "excluded" from it.

"In the early 1990s, there was a turnabout in the scenario. Industry was deeply affected by the market opening: the unemployment and informal employment increased significantly, along with the amount of unsalaried people. (Leite, 2003, p. 105).

If on one hand, there are changes in organizational structures, on the other, new demands have been made from the individuals of these organizations, strongly affecting them.

Now, the individual represents the new discourse of the organization: he/she must have responsibility, autonomy, and cooperative skills in addition to the traditional expertise so emphasized by human resources departments: skills and competences. However, this situation can lead to conflicts, since the individual and the company have different realities, desires, and intentions.

For these reasons, Pagès (1987) states that corporations are mediation systems that deal with employees on one side, and the company on the other side. This system functions as an alliance between the companies' restrictions and the individual privileges. 
People are wary of new situations. This is natural up to a certain point. Some of them can develop pessimistic and resentful behaviors due to their fear of not adapting to the frequent changes in corporations. Such changes deeply interfere in the relation between individual and work.

Human beings steer their behavior according to complex and mutable objectives. Therefore, it is important to first understand the basic human objectives in a society to be able to understand people's behavior.

According to Maslow's hierarchy of needs (Stephens and Heil, 1998), the first need that compels people to look for a job is physiological: it guarantees the survival of that individual and his/her family. Work is a means to obtain food, clothing, housing, education, and health, among other things. People often work excessively, not taking the time needed for their bodies and minds to recover before going back to work.

The second need that leads people to look for jobs is the safety that a long-lasting relation could give them - at least theoretically. Arbitrary administrative actions can make employees insecure about their stability in the job.

The third need is social; very important to individuals, as it brings feeling of acceptance, association, and belonging to a group. When social needs are not fulfilled, people become resistant, antagonistic, and even hostile towards others around them.

Fourth, is esteem - workers seek to build reputation, inc pendence, and self-confidence.

At last, comes self-actualization. Workers seek self-development, creativity and self-expression to reach their ow potential.

Several workers spend years strugglin

employability, and when they do, it is usually for short periods.

Maslow (Stephens and Heil, 1998) asserts that not everyone reaches the top of the pyramid of needs. Some of them, due to different circumstances, worry deeply about self-actualization; others stick to the esteem needs. A number of people focus on social needs, and many others focus exclusively on safety and physiological needs without being able to fulfill them. Those last are called "the outcast".

Society - especially the capitalist - discriminates against people who cannot get a job. Workers can remain unemployed or unable to perform activities for years, either because they lack the tools (skills), or because they lack specific knowledge (competences). Workers in this situation feel impotent, which can get worse when they lack formal education. In this case, they have no perspectives of better conditions of living for themselves and for their families. Therefore, many workers end up in informal employment, without any labor rights or guarantees.

On the other hand, corporations protect individuals from their own anxiety, offering a safety system that is concrete, organized, and accepted by the society. In return, workers are expected to assist the company in maintaining its power. They are, therefore, prevented from facing their personal contradictions.

This type of mediation hides contradictory processes and tries to predict and transform any contradictions before they turn into collective conflicts. Contradictions are only faced when they threaten to become open conflicts with the company.

In the same line, Schirato's (2000) research with dismissed employees led to the conclusion that there is no way to look at the relation individual-corporation, other than through its contradiction.

One may think that the companies' positive policies are a way to anticipate conflicts. High salaries, participation in profits, career plans, and bonuses always comewith a price. However, even though technological innovations can affect the quality and quantity of employment in a company or sector, they do not, in principle, affect nationwide employment. The only way we could affirm that larger productivity automatically means less employment would be in an universe ceteris paribus, i.e., if everything else was held constant (Theis, 2009).

A larger productivity does not necessarily lead to unemployment. It may lead to more employment, consumption, free time, or unemployment. The result will depend on a social decision, historically determined by the forms of regulation of both the productive system and the distribution of productivity earnings.

Economy could then be seen in a more undetermined way, and technology would be part of a cumulative historical process. This dynamic vision of technological innovations recognizes the importance of heterogeneity and asymmetries in behaviors and situations. However, people might criticize the theoretical inconsistencies of certain compensation mechanisms and consider that there will be an enormous release of new products after a period when new products are tested, enabling the society to overcome unemployment (Freeman et al, 1982; Romer, 1990).

The systematic search for technological innovations would be a dynamic element of capitalist development encouraged by inter-capitalist competition, constant in the capitalist mode of production. Scientific development would create a new technological paradigm after difficulties and contradictions (institutional, sociopolitical, and in the markets) were developed throughout a technological trajectory (Dosi, 1982).

Nevertheless, it is important that we protect ourselves from any economical and technological determinism - mentioned in neo-Schumpeterian literature - and that we consider that the economical system is full of economical, technological, social, and institutional relations that may or may not favor its operation. A good regulation and articulation of these relations could promote economical growth. On the other hand, its disarticulation would promote crises and the over-

ISSN: 07 I8-2724. (http://www.jotmi.org)

Journal of Technology Management \& Innovation (c) Universidad Alberto Hurtado, Facultad de Economía y Negocios. 
coming of institutional models; of parameters for growth and technical progress; and of modes of regulation (regimes of accumulation, money relations, wage relations, forms of competition, international regimes, and forms of state intervention) (Boyer, 1988; Boyer and Petit, 1990; Petit, 1995).

Therefore, technology has been recognized as a key sustained advantage in the competition among companies and nations. It has promoted changes both in the qualitative composition of work force (technical division, organization and qualification of labor) and in the quantitative or sectorial composition of work force (emergency, development, and descend of activities). Technology has been progressively associated with knowledge (Lundvall and Johnson, 1992) and with new organizational models. Thus, technology is also composed by intangible elements.

At the same time, technology is complexly - and not automatically - related to employment. This relation encompasses economy in work force, compensation forces, and many forms of technical progress under economical, social, and institutional conditions determined by a new form of laissez-faire - dominated by finances.

\section{Methodology}

This study was designed to investigate how leading exec tives of health care institutions explain the causes for unenployment, and how these explanations are related to the personal and family values, in accordance with Schwartz's theoretical model. For that, we used two questionnaires: one to analyze the unemployment causes based on Furnham's research (1982), and the other using Schwartz's Portrait Values Questionnaire (PVQ 21 - short version) (1994), included in the European Social Survey (ESS).

This study follows the principles of a descriptive research. The results are not normative, since the information gathered reflects the opinions of a very specific segment of population (managers and executives in leading positions). Moreover, this study is a work analysis, as it determines the nature of a specific activity (hospital management), and the skills and formation needed by the professionals of this area to maintain their positions.

\section{Description of Participants}

The participants of this research are department managers and executives in leading positions (sector chiefs, section chiefs and supervisors), all of them with ascending careers. These professionals work in six major health care institutions (over 200 beds and 20 types of service), and they work in different sectors (financial, administrative, material, strategic, human resources, information technology, and others).
Three of these institutions are private, and three are public. To preserve the name and image of these institutions, we will call them Hosp-A, Hosp-B, Hosp-C, Hosp-D, Hosp-E, and Hosp-F, since the focus of this research was not to study the characteristics of each institution.

We interviewed 205 participants: 101 are managers (Group I), and 104 are executives in different positions (Group 2). From the total, $130(63.5 \%)$ are men, and 75 (36.5\%) are women. All of them are married and have at least one child. Their age ranges from 18 to 60 years old (average AVG = 29.96; standard deviation STD $=9.14$ ). One hundred and four participants (52\%) have high school to bachelor's degrees, 34 (17\%) have postgraduate certificates (MBA)', and 62 (3I\%) have graduate education (specialization). Men represented over $60 \%$ of managers and executives. There are differences in education, age, and family situation. In Group I, $80 \%$ completed only high school to bachelor's degree, whereas in Group 2, 40\% completed postgraduate or graduate degrees (MBA or specializations). Executives were younger than managers (AVG $=27.64$ to $32.33 ;$ STD $=7.65$ to $9.94 \%$, respectively), which is in accordance with current data from the Brazilian Institute of Geography and Statistics (IBGE - 2007), and with the Intersyndical Department of Statistics and Socioeconomic Studies (DIEESE - 2008). The majority of executives and managers has up to two children $(71.6 \%)$, and the minority (23.5\%) has three to five children. ning the amount of time that those professionals spent unemployed, $52.2 \%$ spent one to six months without a job, $23.9 \%$ spent more than 24 months, $17.4 \%$ were in this condition for seven to twelve months, and 6.5 from 13 to 24 months. Most of them were employed in private hospitals at the time of the research (59.4\%), and 38.6\% worked in public hospitals. The remaining $2 \%$ were employed in both sectors. In terms of working time, the average was 38.4 hours per week (STD = 8.89). Another piece of information collected was that $36.7 \%$ said they rarely take work home, and $32.6 \%$ said they do it frequently or always.

\section{Instruments}

The instruments used were: the PVQ-2I, the "Explanations for Unemployment" Questionnaire, and sociodemographic data that show the insecurities and challenges that executives face.

The "Explanations for Unemployment" Questionnaire had 19 items that covered Furnham's tridimensional model of explanations for unemployment: individualistic explanations (7 items); societal explanations (6 items), and fatalistic explanations ( 6 items). The Brazilian version of the questionnaire

In Brazil, MBA is classified as a postgraduate certificate, not as a masters degree. 
was translated from English, and then back into English. Each item is a sentence with an explanation for unemployment, for example: "indolence and lack of effort of unemployed people" (individualistic); "the educational system does not correspond to the demands of the job market" (societal); and "changes in demography and population" (fatalistic). The participants answered the questionnaire classifying the importance of each cause in a scale from I (extremely important) to 7 (not at all important). When analyzing the data, we inverted the values ( $I$ for not at all important and 7 for extremely important).

Schwartz's Portrait Values Questionnaire (PVQ-2I) has 2I items divided into ten factors according to the motivations described in Schwartz's theory (1994, 2005, 2006a, 2006b). The items are descriptions of a person, and the participant has to compare himself to this person and classify how similar they are (Bilsky, 2009; Pasquali \& Alves, 2004). Each sentence represents a value and suggests ambitions that implicitly refer back to a motivational profile (Schwartz, 2005), for example: "Having a good time is important for him/her. He/ she likes to spoil him/herself". The participants used a scale from I to 5, in which I means "very similar to me", 2 means "similar to me", 3 means "somewhat similar to me", 4 means "very little similar to me", and 5 means "not at all similar to me". When analyzing the data, we inverted the values not at all similar and 5 for very similar to me).

Studies surveys developed in Brazil with the utilization this research instrument, allows to corroborate the scale validation PVQ utilized in this research to the human values study, likewise postulated by the Schwartz theory. However, in spite of validate the circular structure proposed in the theory regarding the superior order values (VOS), the scale presents some ambiguity in the motivational value plan (VM). It is understood that the values must be analyzed as a inter-relational, dynamic and hierarchic system, that establishes axiological priorities that affects, by this means, the individual choices in front of life's multiple circumstances. This way, these priorities influence the behavior in form of an articulate system of values that reinforce and opposite themselves. This aggregated vision of values allows to minimize the problem of the internal consistency from each particular VM, since the relation between them is present in the VOS structure.

At last, the questionnaire had sociodemographic questions: gender, age, educational background, marital status, and amount of children. Concerning occupational features, the participants were asked whether or not they were employed at the time of the survey, and, if not, for how long.

\section{RESULTS AND DISCUSSION}

This section is divided into three subsections to outline the scopes of this analysis. They are: general results of explanations for unemployment and the fear of unemployment; general results of values; and relation between explanations and values.

Relations between general results of unemployment explanations and sociodemgraphic variables.

To analyze whether or not this sample confirmed Furnham's dimensions of explanations for unemployment (societal, individualistic and fatalistic) (1982), we applied the principal component analysis (PCA) and obtained seven scores. Then, in a second try, we performed a factor analysis with varimax rotation, forcing the distribution into three scores (KMO = 0.686). We reached a mixture of items with individualistic, societal, and fatalistic explanations in each score, with factor loadings ranging from 0.35 to 0.68 (first score with 8 items); from 0.36 to 0.62 (second score with 8 items); and from 0.58 to 0.77 (third factor with 3 items). The first two explain $13 \%$ of the variance, and the third explains $9 \%$. The results of this study confirm what the literature had already pointed out: the process of explanation of unemployment causes is highly complex, as people mixture individualistic, societal, and fatalistic explanations.

One of the reasons for that may be the cultural specificity, since, regardless of being employed or unemployed, male or female, or seeing themselves as actors or observers of unemployment, Brazilians evaluate unemployment as a multicausal phenomenon.

In spite of this imprecision of the tridimensional model, for further analyses, we grouped the database into fatalistic, societal, and individualistic items, with one score for each. The objective of this grouping was to proceed to correlations with the personal values variable, without disregarding the implications of this decision.

The results of the whole sample (employed and formerly unemployed participants) indicate that there are no significant differences among the explanations for unemployment, as follows: individualistic explanations (AVG $=5.7 \mathrm{I}$; STD = 0.56), societal (AVG $=6.08 ;$ STD $=0.49$ ), and fatalistic (AVG $=5.57 ;$ STD $=0.57)$. These numbers support the argument that Brazilians believe that unemployment is caused by multiple factors.

Student's t-test of independent samples did not show any significant differences $(p>0.05)$ in the averages of managers in comparison with executives: $[t(20 \mathrm{I})=1.74, p>0.05]$ for individualistic explanations; $[\mathrm{t}(20 \mathrm{I})=1.00, \mathrm{p}>0.05]$ for so-

ISSN: 07 I8-2724. (http://www.jotmi.org)

Journal of Technology Management \& Innovation (c) Universidad Alberto Hurtado, Facultad de Economía y Negocios. 
cietal explanations; and $[t(199)=1.55, p>0,05]$ for fatalistic explanations.

The analysis of variance (one-way ANOVA) showed significant differences between individualistic and fatalistic explanations, and the educational background $[F(2.197)=5.91$, $P$ $<0.05]$, and $[F(2.197)=4.33, p<0.05]$. A post hoc analysis using Tukey's test showed that the average of individualistic explanations is significantly smaller for postgraduate professionals (MBA or specialization) (AVG $=5.55,95 \% \mathrm{Cl}[5.4 \mathrm{l}$, 5.68]) than for those with undergraduate degree (AVG = $5,84,95 \% \mathrm{Cl}[5.74,5.95)] \mathrm{p}<0.05$. The same happens with fatalistic explanations: averages were lower among postgraduate professionals (AVG $=5.41,95 \% \mathrm{Cl}[5.27,5.56])$ than among professionals with undergraduate degrees (AVG = $5.68,95 \% \mathrm{Cl}[5.57,5.79]) \mathrm{p}<0.05$.

These results partially confirm Furnham's. Groups with different educational background showed the same average of societal explanations. However, people with postgraduate degrees (MBA and specializations) showed lower averages of individualistic and fatalistic explanations than people with bachelor's degrees, which goes in the same line as Furnham's data.

\section{Significant relations between general results of sonal values and sociodemographic variables}

Concerning the dimensions of the PVQ-2I (Image I b low), formerly unemployed participants showed different numbers for universalism, benevolence (philanthropy), and security $(M=2.3 \mathrm{I}, \mathrm{DP}=1.25 ; \mathrm{M}=2.83, \mathrm{DP}=$
$=2.60, \mathrm{DP}=1.24$, respectively) than employed participants $(M=2.17, D P=0.86 ; M=2.64, D P=1.20$; and $M=2.68$, DP $=1.00$, respectively). The differences are $t(203)=0.93, p<$ 0.001 for universalism; $\mathrm{t}(203)=1.10, \mathrm{p}<0.05$ for benevolence (philanthropy); and $\mathrm{t}(203)=0.53, \mathrm{p}<0.05$ for security. These results were obtained by Student's t-test of independent samples.

Universalism is the understanding and appreciation of the welfare of all the people and the nature. Benevolence is the attention towards the welfare of people in frequent personal contact. The enhancement of both values means preoccupation with other people's welfare, and the overcoming of self-centered interests. Security, on the other hand, is about appreciating the stability of the society, relationships, and of one's self (Schwartz, 1994; Tamayo \& Porto, 2009).

Thus, results show that executives have higher averages for universalism and benevolence, whereas managers have higher security scores. It means that executives from this sample are more worried about social welfare and the common good, and managers as more worried about keeping their supposedly stable condition.

The analysis of variance (one-way ANOVA) has not shown any significant differences between educational background and the ten types of motivational values (universalism, benevolence, tradition, conformity, power, achievement, hedonism, stimulation, and self-direction). A possible explanation for that is that, unlike the occupational status, the educational background does not activate values nor reflects on hierarchy. In other words, people build values through the

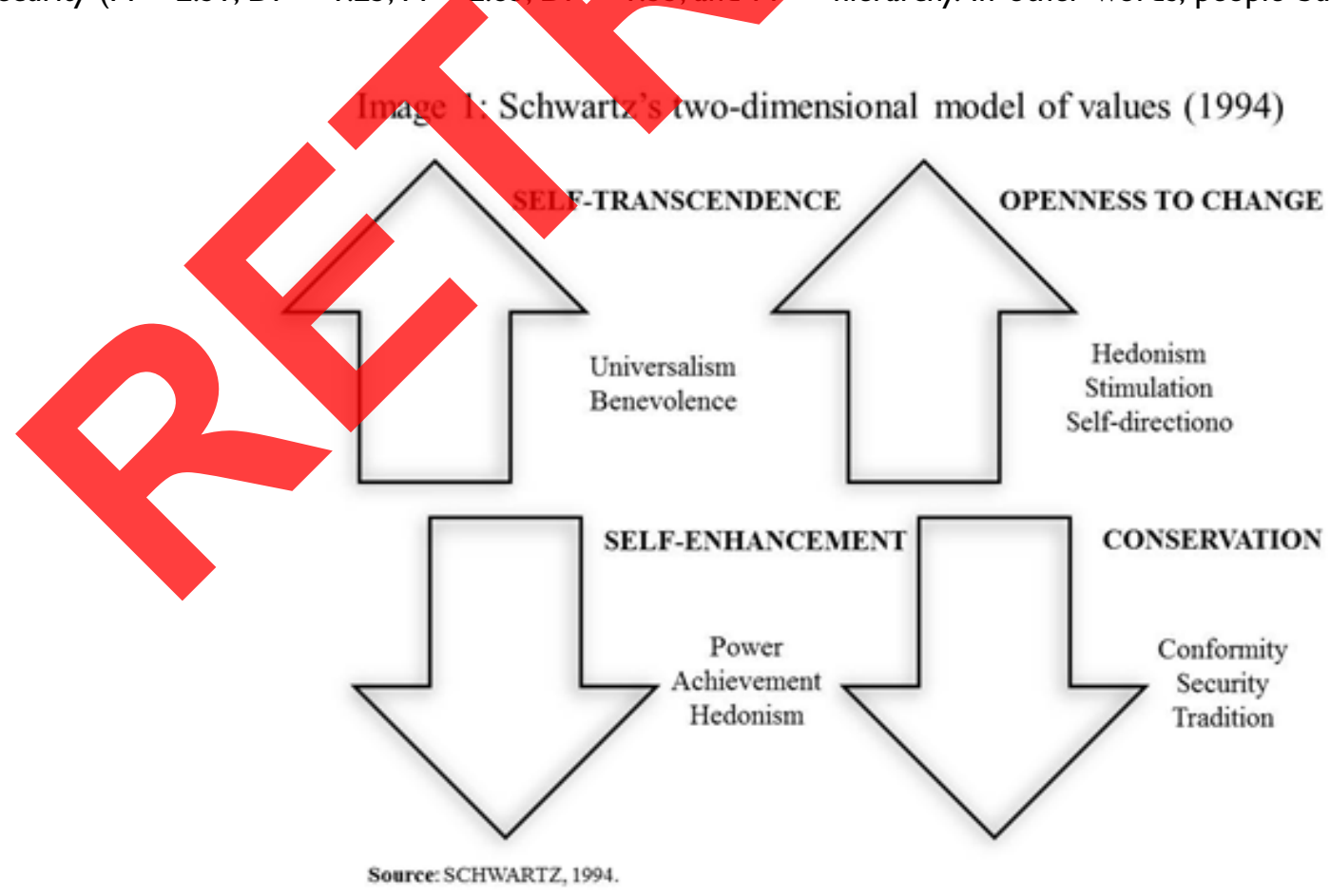

ISSN: 07I 8-2724. (http://www.jotmi.org)

Journal of Technology Management \& Innovation (c) Universidad Alberto Hurtado, Facultad de Economía y Negocios. 
socialization process, not through formal education. Furthermore, people's values are more related to their life experiences than to their educational level.

\section{Relation between values and unemployment expla- nations of the participants (employed and formerly unemployed)}

When analyzing the relation between explanations for unemployment and value dimensions (PVQ-2I), we found some statistically relevant information. The fatalistic explanations (automation in large scale, changes in demography and population, incorporation of new technologies - including information technology -, and merging of companies) are positively correlated with two motivational types within the conservation value: tradition $(r=0.16, p<0.001)$, and security $(r=0.19, p<0.001)$.

From the meaning of conservatism and the fatalistic explanations in the questionnaire, we can understand that the belief that "thing are what they are" demonstrates a tendency to see social events (like unemployment) as something inevitable that cannot be controlled (conservatism) (Almeida e Sobral, 2009). In other words, people with conservation values believe that social problems are consequences of the inevitable development processes.
The correlation between stimulation and individualistic explanations indicates that those who believe in innovation believe that the unemployed have not worked hard enough to get a job. Supposedly, there is an intrinsic belief on the discourse of employability, i.e., on the fact that employment depends on personal efforts to seek innovation (Pereira \& Brito, 2006).

\section{FINAL CONSIDERATIONS}

The insertion of technology into productive processes continues to play a historical role in the capitalist society; it reduces the amount of human labor directly involved in production. This insertion benefits corporations, as it increases productivity and competitiveness. In that sense, technological innoyations (specially communication and information technology) are key factors in the changes in employment quality and quantity.

However, at the same time that technological innovations suppress products, companies, economic activities, and jobs, they also create new products, companies, sectors, economic activities, and, as a consequence, new jobs. In other words, even though technological innovations can affect the quality and quantity of employment, it does not determine its results, especially when we consider the national

Additionally, we must consider that societal exp nations also proved to have a positive correlation with the motivational type called tradition $(r=0.22, p<0.001)$, show ing that unemployment explanations are complexly related with the system of personal values. Societal explanations demonstrate a belief that the government is incompetent in dealing with unemployment and does not elaborate policies that ensure employment throughout the country. Furthermore, the educational system has proved to be inefficient and incongruent with the job market, as it does not enable or qualify people to work.

Moreover, we noticed a positive correlation between individualistic explanations and the motivational type called stimulation $(r=0.16, p<0.05)$. Stimulation is the openness for new experiences and innovation, as opposed to conservatism. Based on the items of the unemployment explanations questionnaire, unemployed people are considered not to be as intelligent or hard-working. They are thought to be indolent and unwilling to adapt to the demands of the job market. They are also considered not to have enough knowledge of their own skills, which could be useful to help them look for alternatives that would qualify them for the job market. Furthermore, they are seen as too proud to accept less qualified jobs in order to maintain employment.
The current economic policy favors developed countries, as they take unilateral protectionist measures that preserve their own economies, but affect developing countries, hampering employment maintenance and growth.

With the harder competition caused by globalization, it became more evident that the high tax burden in countries like Brazil discourages the creation of new companies and the development of the existing ones.

Even though the number of economically active people is rising in Brazil, the poor educational system forces us to import workforce, which is inadmissible considering the unemployment problem.

Our strict employment legislation aggravated the problem; companies wanted and needed to reduce costs, and technology came in handy, as it diminished the amount of job positions and increased productivity.

Technology does cause structural unemployment, and that is inevitable. However, at the same time that it suppresses some job positions, it creates others - not in the same proportion, but at the same speed -, demanding more capable and specialized professionals. 
It is important to point out that people have been discussing the employment crisis, not the work crisis. In a way, people will always need to work; do something for their own survival. Work will always exist, as it is a broader concept that has always been part of human nature and needs. Employment, in turn, is a historical concept; it is a specific form of work exploitation by capital, through wages.

In conclusion, what can we understand about employed and formerly unemployed workers and the relation between unemployment explanations and the values hierarchy?

First, employed and formerly unemployed workers considered societal, individualistic, and fatalistic explanations equally important, without any significant distinction regarding the type of explanation.

The second conclusion is that neither the occupational status, nor the gender of the workers interfere with their explanations for unemployment. Employed or unemployed, man or woman, the Brazilians in this study believe that explanations for unemployment are related to multiple factors (societal, individualistic, and fatalistic). On the other hand, the educational background did interfere in the workers' perception of individualistic and fatalistic explanation! for unemployment. Participants with postgraduate degrees (specialization or MBA) give less individualistic and fatalis explanations for unemployment than participants with bachelor's degree.

The third conclusion is that

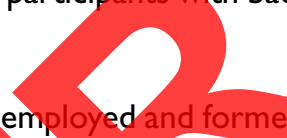
unemployed participants adopt different values. The former are more sensitive to common welfare and to the search for common good (universalism and benevolence), whereas the employed ones are more worried about security (conservatism dimension). The conclusion is that this difference is due to the employed workers being worried about keeping their relatively stable condition.

Finally, the fourth conclusion is that fatalistic and
societal explanations are positively related to the values within the conservation dimension. This fact leads to the conclusion that people that are closer to conservatism tend to believe that social problems are caused by the inevitable social development process and by inappropriate public measures, as opposed to people whose values represent openness to changes.

This ambiguous conclusion supports the argument that explaining the causes of unemployment is a complex process that cannot be perfectly adjusted to a tripartite model that groups different values. For the professionals in our sample (predominantly people with bachelor's and post- graduate degrees), the different types of explanations are not independent. Nevertheless, we point out that the value dimension of openness to changes proved to be related to individualistic explanations, showing that, in a certain way, there has been an incorporation of the discourse that workers are co-responsible for their professional insertion.

In conclusion, even though we recognize the limitations of this study - some of them previously pointed out -, the results lead to paths that should to be thoroughly explored in future studies, such as a redefinition of the theoretical model of explanations of causes for unemployment, and the role of the occupational status (employed and formerly unemployed) in the explanations for unemployment, and in the personal values portra

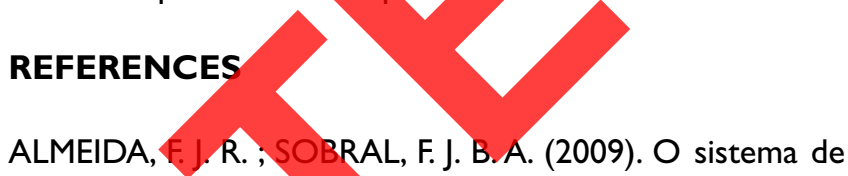
valores humanos de administradores brasileiros: adaptação da escala PVQ para o estudo de valores no Brasil. Revista de Administração Mackenzie, São Paulo, V. I0, Nº. 3, MAl./JUN, p. $101-126$.

BILSKY,W. (2009). A estrutura de valores: sua estabilidade para além de instrumentos, teorias, idade e culturas. Revista de Administração Mackenzie, 10(3), pp. 12-33.

BOYER, R. (1988). "Technical change and the theory of regulation". In: DOSI, G. et alii. (eds.). Technical Change and Economic Theory. Londres: Pinter.

, R.; PETIT, P. (1990). Technical change, cumulative causation and growth: accounting for the contemporary productivity puzzle with some post keynesian theories. Paris: OCDE.

CASTELLS, M. (2007).A sociedade em rede. $10^{a}$ ed. São Paulo: Paz e Terra.

CHICK, V. (1983). Macroeconomia Após Keynes: um reexame da Teoria Geral. Rio de Janeiro: Forense Universitária.

DIEESE - DEPARTAMENTO INTERSINDICAL DE ESTATÍSTICA E ESTUDOS SOCIOECONÔMICOS. (2008). Trajetórias da juventude nos mercados de trabalho metropolitanos: mudanças na inserção entre 1998 e 2007. / DIEESE. - São Paulo. 108 p. - (Biblioteca DIEESE)

DOSI, G. (1982).“Technological paradigms and technological trajetories”. Research Policy, v. I I, pp. I47-I63.

DOWBOR, L. (2002). O que acontece com o trabalho? São Paulo: Senac. 
FARIA, J. H. (20I0). Trabalho, tecnologia e sofrimento: as dimensões desprezadas do mundo do trabalho. Revista de Trabalho e Tecnologia, Periódico técnico científico dos programas de pós-graduação em tecnologia dos CEFETs - PR/ MG/RJ, Curitiba,Ano 04, n. 6, pp. I57-I77.

FERNÁNDEZ. F. G.; BORJAS, A. E. C. (2008). The Relationship between Information and Communication Technologies and New Organizational Forms: Reference of the Manufacturing Industry in the Area of Carabobo, Venezuela. Journal of Technology Management \& Innovation. Volume 3, Issue 4, Pp. I52-165.

FREEMAN, C.; CLARK, J.; SOETE, L. ( 1982). Unemployment and technical innovation: a study of long waves and economic development. Londres: Frances Printer.

FURNHAM, A. (1982). Explanations for unemployment in Britain. European Journal of Social Psychology, 12, pp. 335352.

GUIMARÃES, N. (2002). Por uma sociologia do desemprego. Revista Brasileira de Ciências Sociais, São Paulo, vol.17, no.50, pp. I04-121.

\section{IBGE - INSTITUTO BRASILEIRO DE GEOGRAFIA} TATÍSTICA. (2007). Pesquisa mensal de emprego - $S$ relatórios metodológicos, $2^{\mathrm{a}}$ Edição,V.23, Rio de Janeiro.

ILO - INTERNATIONAL LABOR (2012), Global Employment Trends 20 tional Labour Office.

KEYNES, J. M. (1936). Teoria Geral do Emprego, do Juro e da Moeda. São Paulo: Abril Cultural (Coleção Os Ecoñomistas - 1983).

LEITE, M. P. (2003). Trabalho e sociedade em transformação: mudanças produtivas e atores sociais. São Paulo: Fundação Perseu Abramo.

LUNDVALL, B.A. JOHNSON,B. ( 1992). "The learning economy". Conference on structural change and the regulation of economic systems. París.

NAISBITT,y. (1995). Global paradox. Montreal-Canadá:Avon Books.

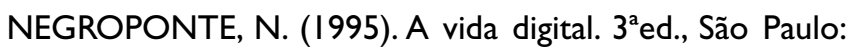
Companhia das Letras.

OLIVEIRA, I.; CUNHA, M. S. (20I0). A evolução recente do desemprego no mercado de trabalho brasileiro. Revista Economia \& Tecnologia, Paraná, Ano 06,Vol. 22, Julho/Setembro, Pp. $7 \mathrm{I}-77$.

ISSN: 07/8-2724. (http://www.jotmi.org)

Journal of Technology Management \& Innovation (c) Universidad Alberto Hurtado, Facultad de Economía y Negocios.
OLIVEIRA, J. F.; MAÑAS, A. V. (2004). Tecnologia, trabalho e desemprego: um conflito social. São Paulo: Érica.

PAGÈS, M. (1987). O Poder das Organizações: a dominação das multinacionais sobre os indivíduos. São Paulo:Atlas.

PASQUALI, L.; ALVES, A. R. (2004). Validação do Portraits Questionnaire - PQ de Schwartz para o Brasil (Versão Eletrônica).Avaliação Psicológica, I3(2), P

PEREIRA, M. C.; BRITO, M. J. (2006). Desemprego e subjetividade no contexto brasileiro: uma análise interpretativa sob a ótica dos excluídos do mercado de trabalho industrial. Revista Mal-estar e Subjetividade, I(1), Pp.

PETIT, P. (1995).“'Technology and employment: key questions in a context of high unemplyment". Review STI. OCDE, n. I5, set.

ROMER,P.(1990). “Endogenous technological change”. Journal of Political Economy. Part 2, v.98, n.5, pp. S 7I-S 102.

SCHIRATO, M. A. (2000). O Feitiço das Organizações. São Paulo: Ed.Atlas.

SCHWARTZ,S.H. (1994). Are there universal aspects in the structure and contents of human values? Journal of Social Issues, 50(4), pp. 1 9-45.

S. H. (2005).Validade e aplicabilidade da teoria de valores. In A. Tamayo, \& J. B. Porto (Orgs.), Valores e comportamentos nas organizações. Petrópolis:Vozes, pp. 56-95.

S. H. (2006a). Há aspectos universais na estrutura e no conteúdo dos valores humanos? In M. Ros, \& V.V. Gouveia (Orgs.), Psicologia social dos valores humanos: desenvolvimentos teóricos, metodológicos e aplicados. São Paulo: Senac, pp. 55-85.

S. H. (2006b). Basic human values: an overview. Recuperado de http://www.yourmorals.org/schwartz.2006. basic.human.values.pdf

SOUZA, N. A. (2008). Economia brasileira contemporânea: de Getúlio a Lula. São Paulo:Atlas.

STEPHENS, D.; HEIL, G. (1998). Maslow on Management. NY: Wiley, (Note: previously published as: Eupsychian Management: A Journal Homewood, IL: Irwin-Dorsey, 1965)

TAMAYO,A.; PORTO, J. B. (2009).Validação do Questionário de Perfis de Valores (QPV) no Brasil. Psicologia:Teoria e Pesquisa, 25(3), pp. 369-376. 
THEIS, I. M. (2009). Ciência \& tecnologia e desenvolvimento geográfico desigual no Brasil. Revista Redes, Santa Cruz do Sul, v. I4, n. I, jan./abr, pp. 62 - 8 I.

TOFFLER, A. (2007).A terceira onda. $29^{\mathrm{a}}$ ed., Rio de Janeiro: Record.

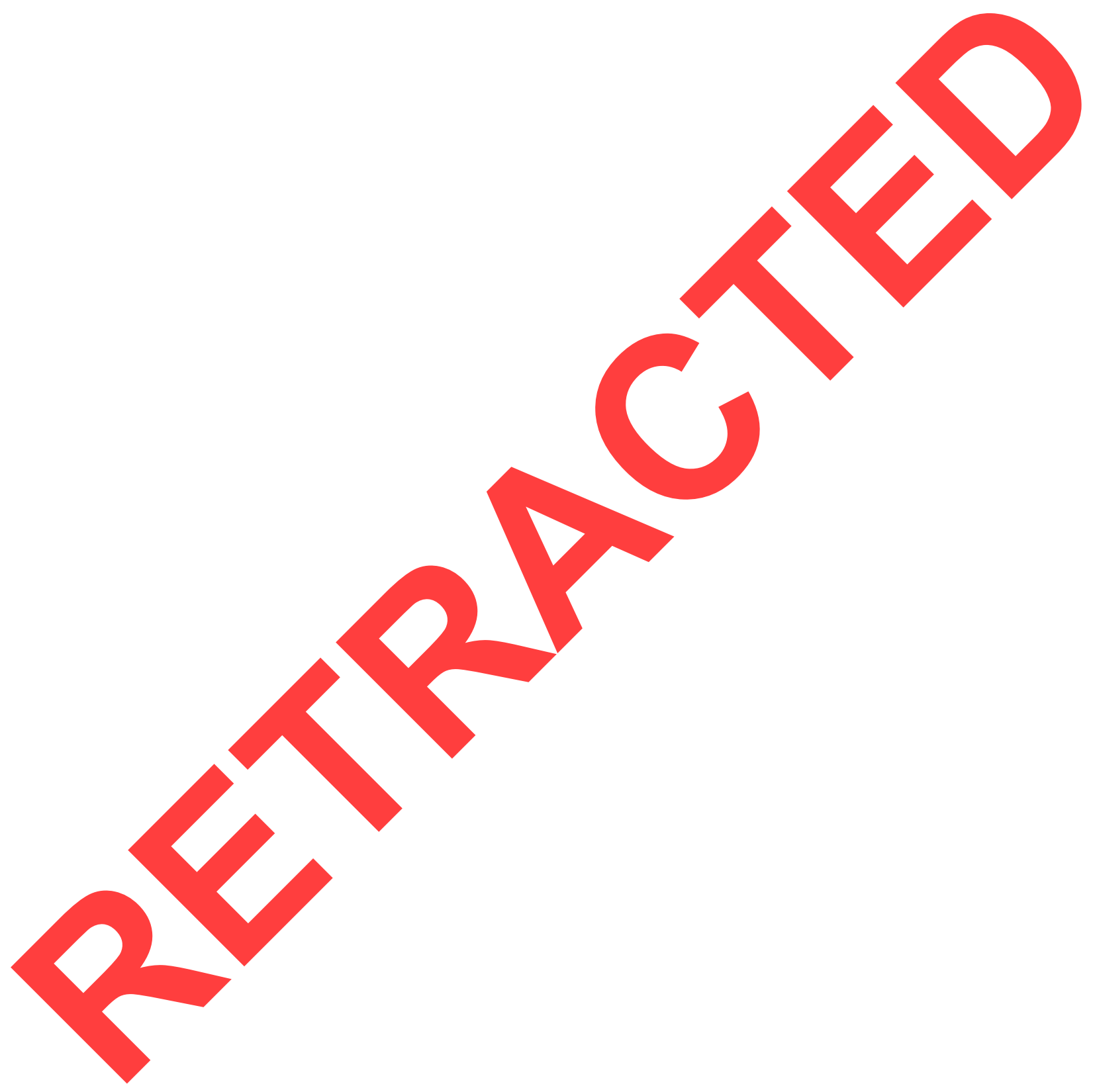

